\title{
Role of cathepsin A and cathepsin $C$ in the regulation of glycosidase activity
}

\author{
Alina Minarowska ${ }^{1}$, Łukasz Minarowski², Alicja Karwowska ${ }^{3}$, \\ Anna Justyna Milewska ${ }^{4}$, Marek Gacko ${ }^{5}$
}

\author{
${ }^{1}$ Department of Human Anatomy, Medical University of Bialystok, Poland \\ ${ }^{2}$ Department of Lung Diseases and Tuberculosis, Medical University of Bialystok, Poland \\ ${ }^{3}$ Department of Epidemiology and Hygiene, Medical University of Bialystok, Poland \\ ${ }^{4}$ Department of Statistics and Medical Informatics, Medical University of Bialystok, Poland \\ ${ }^{5}$ Department of Vascular Surgery, Medical University of Bialystok, Poland
}

\begin{abstract}
Increased tissue activity of cathepsin A and cathepsin C can be observed in many pathological conditions. It is associated with an enhanced degradation of glycosaminoglycans, proteoglycans, and glycoproteins, and results in their decreased tissue content. Cathepsin $\mathrm{C}$ releases the glycosidases from complexes formed with cathepsin A, and reinstates their activity. In this review a current state of knowledge is presented concerning the regulation of selected glycosidases activity by cathepsin A (EC 3.4.16.1) and C (EC 3.4.14.1). (Folia Histochemica et Cytobiologica 2012, Vol. 50, No. 1, 20-24)
\end{abstract}

Key words: cathepsin A, lysosomal carboxypeptidase A, cathepsin C, dipeptydyl peptidase I, glycosidase activity

More than sixty lysosomal hydrolases digest macromolecular compounds: proteins, polysaccharides, lipids, and nucleic acids at acidic $\mathrm{pH}$. The lack or deficiency of a certain lysosomal enzyme resulting from genetic defect or inactivation can lead to the development of a storage disease [1]. A disease can be classified as a lysosomal storage disorder if it fulfils the following three criteria: 1) the lack or decreased activity of at least one lysosomal enzyme, 2) the stored substance is normally degraded in lysosomes, and 3) it is stored inside the lysosomes [2].

Cathepsin A (EC 3.4.16.1) prevents the processes involved in lysosomal storage. Cathepsin A forms complexes with glycosidases, protecting them in this way against proteolytic inactivation [3, 4]. Decreased lysosomal content of cathepsin A leads to the inactivation of several glycosidases and accumulation of glycosaminoglycans. Cathepsin C (EC 3.4.14.1) is also

Correspondence address: L. Minarowski, Dept. of Lung Diseases and Tuberculosis, Medical University of Bialystok, Poland; tel.: + 488574095 24, fax: + 488573241 49; e-mail: lukasz.minarowski@gmail.com involved in glycosaminoglycan metabolism. Cathep$\sin C$ releases the glycosidases from complexes formed with cathepsin A, and reinstates their activity [5].

\section{Cathepsin A}

Cathepsin A is multifunctional lysosomal protein that acts as a carboxypeptidase and forms complexes with glycosidases at $\mathrm{pH}$ between 4.5 and 5.5; it exhibits amidase and esterase activity at $\mathrm{pH} 7.0[5,6]$. One molecule of cathepsin A is composed of 438 amino acid residues assembled into two subunits - cortical and apical one with molecular masses of $32 \mathrm{kDa}$ (Ala1-Arg284) and $20 \mathrm{kDa}$ (Met285-Tyr438), respectively (Figure 1). The subunits are held together with disulfide bonds C60-C361 and form a monomer of cathepsin A [7]. Its catalytic site is built of Ser150, Asp356, and His415 amino acid residues. Cathepsin A monomer has a molecular mass of $52 \mathrm{kDa}$ and measures $60 \times 50 \times 70 \AA$ [ [8].

Under acidic $\mathrm{pH}, 60-70 \%$ of cathepsin A exists as homodimers with $104 \mathrm{kDa}$ molecular mass [6]. The remaining $30-40 \%$ is present in the form of a twocomponent, enzymatically active complex with beta- 


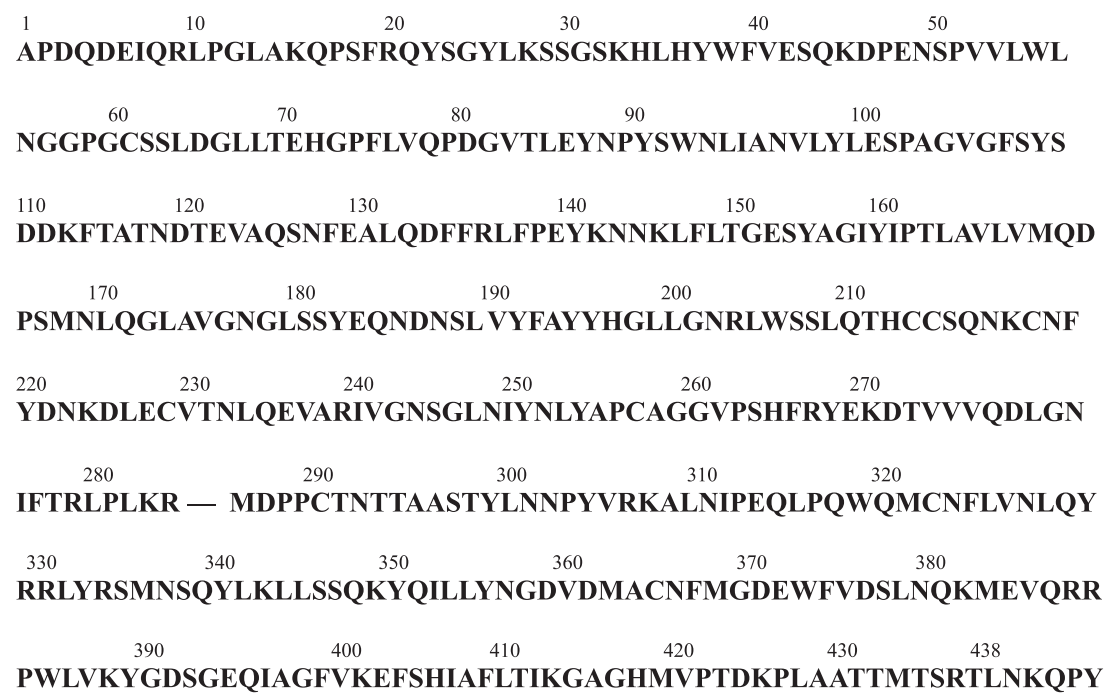

Figure 1. Amino acid sequence of cathepsin A: A1-R284 - 32 kDa subunit; M285-Y428 - 20kDa subunit; C - C disulfide bond binding the subunits; S150-D356-H415 — catalytic triad; N17, N291 glycosylated rests; Q76-Y84, V306-E401 — beta-galactosidase binding sequences [8]

Table 1. Amino acid composition of cathepsin A [44]

\begin{tabular}{lccc} 
Amino acid* & Cathepsin A & \multicolumn{2}{c}{ Subunit } \\
\hline & & 32 kDa & 20 kDa \\
\hline Ala (A) & 23 & 14 & 9 \\
\hline Arg (R) & 15 & 8 & 7 \\
\hline Asn (N) & 33 & 22 & 11 \\
\hline Cys (C) & 9 & 6 & 3 \\
\hline Phe (F) & 20 & 14 & 6 \\
\hline Gln (Q) & 26 & 15 & 11
\end{tabular}

\begin{tabular}{lccc}
\hline Gly $(\mathrm{G})$ & 30 & 23 & 7 \\
\hline His $(\mathrm{H})$ & 8 & 6 & 2 \\
\hline
\end{tabular}

\begin{tabular}{llll}
\hline Ile (I) & 12 & 7 & 5 \\
\hline Asp (D) & 22 & 15 & 7 \\
\hline Glu (E) & 19 & 14 & 5 \\
\hline Leu (L) & 51 & 35 & 16
\end{tabular}

\begin{tabular}{llll}
\hline Lys $(\mathrm{K})$ & 20 & 11 & 9 \\
\hline Met $(\mathrm{M})$ & 10 & 2 & 8 \\
\hline Pro (P) & 25 & 16 & 9 \\
\hline Ser (S) & 33 & 24 & 9 \\
\hline $\operatorname{Thr}(\mathrm{T})$ & 21 & 11 & 10
\end{tabular}

\begin{tabular}{lccc}
\hline $\operatorname{Trp}(\mathrm{W})$ & 7 & 4 & 3 \\
\hline $\operatorname{Tyr}(\mathrm{Y})$ & 27 & 18 & 9 \\
\hline $\operatorname{Val}(\mathrm{V})$ & 27 & 19 & 8 \\
\hline Sum of amino acids & 438 & 284 & 154 \\
\hline
\end{tabular}

*Three-and one-letter code -galactosidase [7]. Its beta-galactosidase-binding contact surface is formed of Gln76-Tyr84 and Val386-Glu391 sequences. Dimeric molecule of cathepsin A binds to the monomer of beta-galactosidase $(64 \mathrm{kDa})$ forming a heterotrimer with $168 \mathrm{kDa}$ molecular mass. Four molecules of the heterotrimer form macrocomplex with $680 \mathrm{kDa}$ molecular mass [6]. At pH 7.5, this macrocomplex splits into 8 molecules of cathepsin A and 4 molecules of beta-galactosidase [7, 9] (Figure 2). Sodium dodecyl sulfate (SDS) dissociates this complex into monomers that are further split into sub-

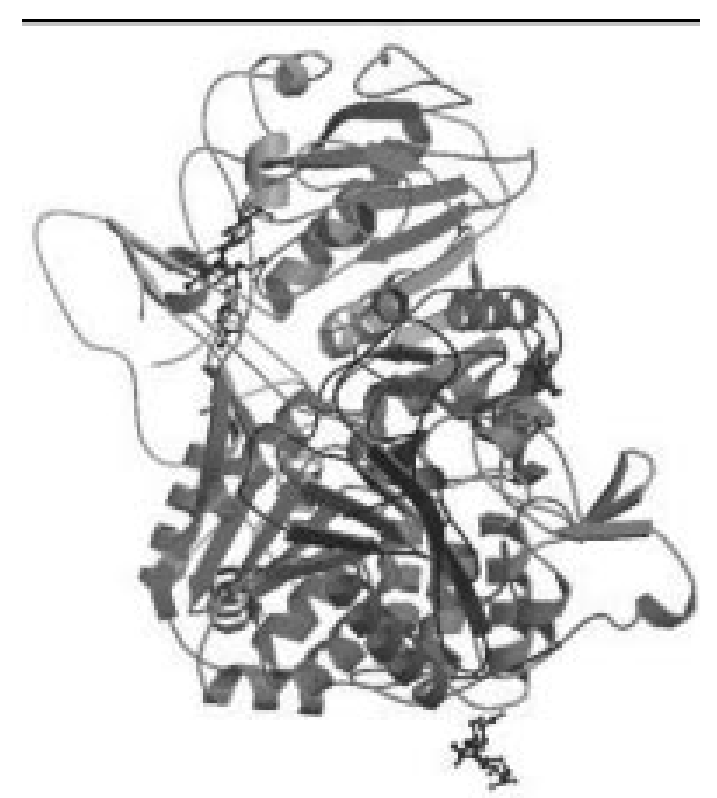

Figure 2. Model of cathepsin A molecule monomer [adopted from 9]. $\bullet-\bullet-\bullet-$ amino acids of catalytic triad 
Table 2. Glycosidases forming complexes with cathepsin A

\begin{tabular}{lclc} 
Glycosidase & $\begin{array}{c}\text { Molecular mass } \\
\text { kDa }\end{array}$ & Substrate & Function \\
\hline $\begin{array}{l}\text { Beta-D galactosidase }(\beta \text {-Gal) } \\
\text { EC 3.2.1.23 }\end{array}$ & 64.0 & Galactosaminoglycans & Splits off galactose \\
\hline $\begin{array}{l}\text { Neuraminidase (Neu) } \\
\text { EC 3.2.1.18 }\end{array}$ & 48.3 & $\begin{array}{l}\text { Sialoglycosaccharides } \\
\text { (mucopolysaccharides) }\end{array}$ & Splits off neuraminic acid \\
\hline $\begin{array}{l}\text { 6-N-galactosamine N-acetyl-6- } \\
\text {-sulfate sulfatase (GALNS) } \\
\text { EC 3.1.6.4 }\end{array}$ & 57.0 & $\begin{array}{l}\text { Glycosaminoglycans, keratan } \\
\text { sulfate, chondroitin 6-sulfate }\end{array}$ & Splits off sulfate ion
\end{tabular}

units as a result of the addition of the reducing compound. After reducing $\mathrm{pH}$ to 4.5 , macrocomplex with $680 \mathrm{kDa}$ molecular mass is formed again. The formation of this complex protects beta-galactosidase against degradation and proteolytic inactivation [10, 11]. Complex of cathepsin A with beta-galactosidase is isolated by means of affinity chromatography on $p$-aminophenyl-beta-D-thiogalactopyranoside-agarose [14]. Obtained complex of cathepsin A and beta-galactosidase is dissociated at $\mathrm{pH} 7.5$ and fractioned into its components by means of gel chromatography technique with Shim-pack Dial-3000 column. About 1\% of cathepsin A molecules is present as a polyenzymatic macrocomplex with beta-galactosidase, $\mathrm{N}$-acetyl-alpha-neuraminidase, and $\mathrm{N}$-acetylgalactosamine-6-sulfate sulfatase [12,13]. This macrocomplex has a molecular mass of approximately $1280 \mathrm{kDa}$ $[7,14,15]$. Table 2 summarizes the characteristics of glycosidases that are bound by cathepsin A.

Inherited deficiency or point mutations in the amino acid sequence of cathepsin A (Q21R, S23Y, W37R, S61L, V104M, L208P, Y221N, Y351C, M365T, G389S, F398V) inhibit the formation of dimeric forms and complexes with glycosidases [16-18]. Degradation and inactivation of beta-galactosidase and neuraminidase are reflected by a secondary deficiency of those enzymes, leading to the accumulation of galactosaminoglycans and sialoglycosaccharides, and as a consequence to the storage disease - mucopolysaccharidosis IV B and galactosialidosis $[19,20]$. Degradation of beta-galactosidase is catalyzed by cysteine cathepsins [21]. Leupeptin, an inhibitor of cathepsins, halts this process. Decreased activity of cathepsin A can be observed in the course of muscular dystrophy [22] and in multiple sclerosis [23].

\section{Cathepsin C}

Cathepsin C also participates in the regulation of glycosidase activity. It is a lysosomal cysteinyl peptidase - an enzyme that cleaves off dipeptides from the $\mathrm{N}$-terminus of peptides and proteins [24, 25]. Moreover,

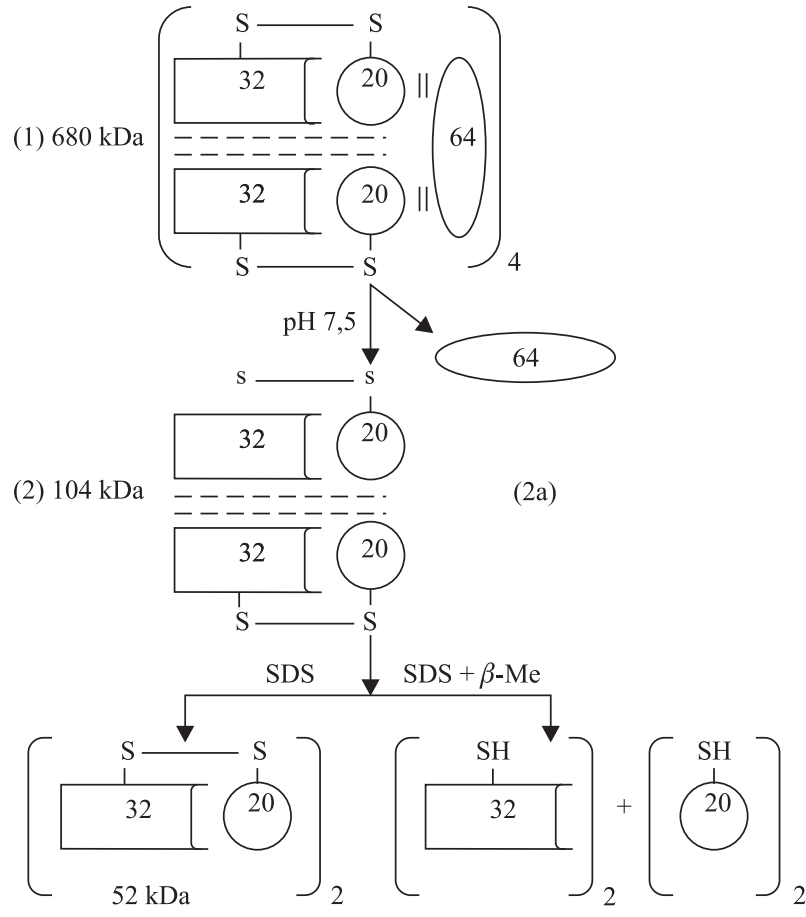

(3)

(4)

(5)

Figure 3. Macrocomplex of cathepsin A with beta-galactosidase [according to 41]. At pH 7.5 the complex of cathepsin A and beta-galactosidase (1) is dissociated into two cathepsin homodimers (2) and beta-galactosidase 2a); sodium dodecyl sulfate (SDS) dissociates homodimer of cathepsin A into two monomers (3), while beta-mercaptoethanol/B-Me/ splits them further into $32 \mathrm{kDa}(4)$ and $20 \mathrm{kDa}$ subunits (5). $\mathrm{S}-\mathrm{S}$ - disulfide bonds binding subunits of the monomer; $=-$ hydrophobic bonds that bind the monomers

it hydrolyses dipeptide esters, amides, anilides, and beta-naphtylamides [26]. Additionally, cathepsin C shows the activity of transpeptidase [27]. It catalyzes hydrolysis at $\mathrm{pH}$ 5.0-6.0 and transpeptidation at $\mathrm{pH}$ 6.8-7.0 [4]. Cathepsin $\mathrm{C}$ is activated by chloride anions and sulfhydryl compounds [28].

One molecule of human cathepsin $\mathrm{C}$ is built of 206 amino acid residues, arranged in four polypeptide chains with a total molecular mass of approximately $200 \mathrm{kDa}$ [29]. Its spatial model is presented in Figure 4. 


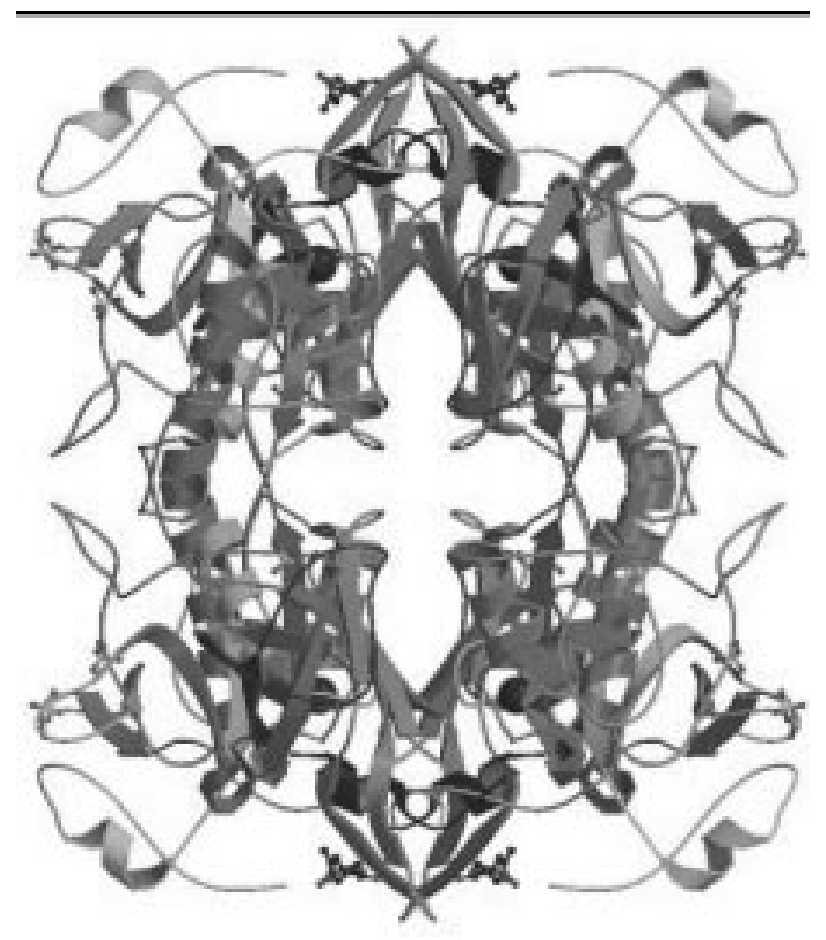

Figure 4. Model of cathepsin C molecule [adopted from 44]

The role of cathepsin $\mathrm{C}$ in the regulation of lysosomal enzymatic activity involves the release of beta-galactosidase and neuraminidase from complex with cathepsin A (Figure 5). This process requires the presence of chloride anions $\left(\mathrm{Cl}^{-}\right)$and sulfhydryl compounds [4, 30]. Released beta-galactosidase, neuraminidase, and cathepsin A exhibit normal activity. Genetic mutation and reduced activity of cathepsin C cause Papillon-Lefevre syndrome characterized by palmoplantar keratoderma, periodontitis, and muscular dystrophy [3, 42].

Increased tissue activity of cathepsin A and cathepsin $\mathrm{C}$ can be observed in many pathological conditions [24, 26, 31-34]. It is associated with an enhanced degradation of glycosaminoglycans, proteoglycans, and glycoproteins, and results in their decreased tissue content [35-40].

\section{References}

1. Neutfeld ET. Lysosomal storage disease. Ann Rev Biochem. 1991;60:257-280.

2. Holtzman E. Lysosoms. Plenum Press, New York, London 1989.

3. D'Azzo A, Hoogeveen AT, Reuser JJ, Robinson H, Galjaard H. Molecular defect in combined $\beta$-galactosidase and neuraminidase deficiency in man. Proc Natl Acad Sci USA. 1982;79:4535-4539.

4. D'Agrosa RM, Callahan JW. In vitro activation of neuraminidase in the $\beta$-galactosidase-neuraminidase-protective protein complex by cathepsin C. Biochem Biophys Res Commun. 1988;157:770-775.

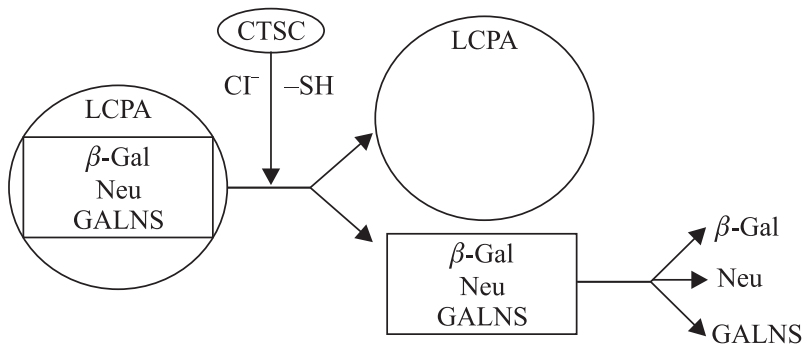

Figure 5. Proposed model of cathepsin C (CTSC) regulated dissociation of multienzyme complex: LCPA — cathepsin $\mathrm{A} ; \beta$-Gal $-\beta$-galactosidase; $\mathrm{Neu}-$ neuraminidase; GALNS - 6-N-galactosamine N-acetyl-6-sulfate sulfatase; $\mathrm{Cl}^{-}$- chloride ions; - $\mathrm{SH}$ - sulfhydryl group

5. Siergiejuk M, Gacko M, Worowska A. Cathepsin A activity of a parietal thrombus of an abdominal aortic aneurysm. Folia Histochem Cytobiol. 2011;49:10-12.

6. Pshezhetsky AV. Lysosomal carboxypeptiodase A. In: Handbook of Proteolytic Enzymes. Acad Press, San Diego, USA, Barrett AJ, Rawling ND, Woessner JF eds. 1998, vol. II:1923$-1929$.

7. Pshezhetsky AV, Potier M. Direct affinity purification and supramolecular organization of human lysosomal cathepsin A. Arch Biochem Biophys. 1994;313:64-70.

8. Rudenko G, Bonten E, d'Azzo A, Hol WGJ. The atomic model of the human protective protein/cathepsin A. Proc Natl Acad Sci USA. 1998;621-625.

9. Rudenko G, Bonten E, d'Azzo A, Hol WGJ. Three-dimensional structure of the human human "protective protein": structure of the precursor form suggest a complex activation mechanism. Current Biol. 1995;3:1249-1259.

10. Pshezhetsky AV, Elsliger MA, Vinogradova MV, Potier M. Human $\beta$-galactosidase-cathepsin A complex: definition of the $\beta$-galactosidase binding interface on cathepsin $\mathrm{A}$. Biochemistry 1995;34:2431-2440.

11. Galjart NJ, Morrean H, Willemsen R, Gillemans N, Bonten EJ, d'Azzo A. Human lysosomal protective has cathepsin A-like activity distinct from its protective function. $J$ Biol Chem. 1991;226:14754-14762.

12. Hoogeveen AT, Verheijen FW, Galjaard H. The relation between human lysosomal $\beta$-galactosidase and its protective protein. J Biol Chem. 1983;258;12143-12146.

13. Bonten EJ, d'Azzo A. Lysosomal neuraminidase catalytic activation in insect cells is controlled by the protective protein/cathepsin A. J Biol Chem. 2000;275:37657-37663.

14. Pshezhetsky AV, Potier M. Stechiometry of the human lysosomal carboxypeptidase- $\beta$-galactosidase complex. Biochem Biophys Res Commun.1993;195:354-362.

15. Pshezhetsky AV, Potier M. Association of N-acetylo-galactosamine-6-sulfate sulphatase with the multienzyme lysosomal complex of $\beta$-galactosidase, cathepsin A and neuraminidase: possible implication for intralysosomal catabolism of keratin sulphate. J Biol Chem. 1996;271:28359-28365.

16. Shimoyo M. Fukuhara Y, Otoh K, Oshima A, Sakuraba H, Suzuki Y. Protective protein gene mutations in galactosialidosis. J Clin Invest. 1993;91:2393-2398.

17. Zhou XY, Galjart NJ, Willemsen R, Gillemans N, Galjard H. A mutation in a mild form of galactosialidosis impairs dimerization of the protective protein and renders it unstable. EMBO J. 1991;10:4041-4048. 
18. Zhou XY, Van der Spoel A, Rottier R, Hale G, Willemsen R, Berry GT. Molecular and biochemical-analysis of protective protein cathepsin A mutations: correlation with clinical severity in galactosialidosis. Hum Mol Genet. 1996;5:1977$-1987$.

19. Tranchemontagne J, Michaud L, Potier M. Deficient lysosomal carboxypeptidase activity in galactosialidosis. Biochem Biophys Res Commun. 1990;168:22-29.

20. Verhijem F, Palmeri S, Hoogeveen AT, Galjard H. Human placental neuraminidase: activation, stabilization and association with $\beta$-galactosidase and its "protective" protein. J Biochem. 1985;149:315-321.

21. Hiraiwa M. Cathepsin A/protective protein: an unusual lysosomal multifunctional protein. Cell Mol Life Sci. 1999;56:894-907.

22. Hinek A, Phazhetsky AV, von Itzstein M, Starcker B. Lysosomal sialidase (neuraminisae-1) is target to the cell surface in a multiprotein complex that facilitates elastic fiber assembly. J Biol Chem. 2006;281:3598-3710.

23. Feng C, Li J, Zuo Z. Expression of the transcription factor regulatory factor X1 in the mouse brain. Folia Histochem Cytobiol. 2011;49:344-351.

24. Kase R, Itoh K, Takiyama N, Oshima A, Sakuraba H, Suzuki Y. Galactosialidosis: simultaneous deficiency of esterase, carboxy-terminal deamidase and acid carboxypeptidase activities. Biochem Biophys Res Commun. 1990;172: 1175-1179.

25. Hiruma H, Kawakami T. Characteristics of weak base-induced vacuoles formed around individual acidic organelles. Folia Histochem Cytobiol. 2011;49:272-279.

26. Kotani M, Yamada H, Sakuraba H. Cytochemical and biochemical detection of intracellularly accumulated sialyl glycoconjugates in sialidosis and galactosialidosis fibroblasts with Macckia amurensis. Clin Chim Acta. 2004;344:131-135 .

27. Pagano MB, Bartoli MA, Ennis TL, Mao D, Simmonds PM, Thompson RW, Han CT. Critical role of dipeptidyl peptidase I in neutrophil recruitment during the development of experimental aortic aneurysms. Proc Natl Acad Sci USA. 2007;104:2855-2860.

28. D'Azzo A, Andria G, Strisciuglio I, Galjaijaard H. Galactosalidosis. In: Scriver CR, Beaduet AL, Sly WS eds, The metabolic and molecular bases of inherited disease, Valle DMc Graw-Hill, New York. 1995, vol. 2:2835-2837.

29. Pshezhetsky AV, Ashmarina M. Lysosomal multienzyme complex: biochemistry, genetics and molecular pathophysiology. Prog Nucl Acid Res Mol Biol. 2001;69:81-114.

30. D'Agrosa R, Hubbes M, Zhang S, Shankaran R, Callahan JW. Characteristics of the b-galactosidase-carboxypeptidase complex in GMJ-gangliosidosis and b-galactosialidosis fibroblast. Biochem J. 1992;285:833-838.
31. Bierc M, Minarowski L, Woźniak L, Chojnowska S, Knas M, Szajda S, Zwierz K. The activity of selected glycosidases in salivary gland tumors. Folia Histochem Cytobiol. 2010;48:471-474.

32. Dariusz Szajda S, Waszkiewicz N, Stypułkowska A, Dadan J, Zwierz K. Lysosomal exoglycosidases in serum and urine of patients with pancreatic adenocarcinoma. Folia Histochem Cytobiol. 2010;48:351-357.

33. Dice JT. Lysosomal pathways of protein degradation. Landes Biosciences, Austin, TX, 2000.

34. Morreau H, Galjart NJ, Willemsen R, Gillemans N, Zhou XY, d'Azzo A. Human lysosomal protective protein glycosylation, intracellular transport and association with b-galactosidase in the endoplasmic reticulum. J Biol Chem. 1992;67:17949-17956.

35. Ostrowska H, Krikowska K, Kalinowska J, Orłowska M, Lengiewicz I. Lysosomal high molecular Wright multienzyme complex. Cell Molec Biol Lett. 2003;8:19-24.

36. Galjard NJ, Gillemans N, Mejer D, a'Azzo A. Mouse" protective protein" cDNA cloning sequense comparison and expression. J Biol Chem. 1990;265:4678-4684.

37. Ostrowska H, Wójcik C, Worowski K. Cathepsin A and chymotrypsin-like activity of the proteasome in human blood platelets. Folia Histochem Cytobiol. 1999;37:153-154.

38. Minarowska A, Minarowski L, Karwowska A, Gacko M. Regulatory role of cathepsin D in apoptosis. Folia Histochem Cytobiol. 2007;45:159-163.

39. Hiraiwa M, Saitoh M, Arai N, Shiraishi T, Odani S, Uda Y. Protective protein in the bovine lysosomal b-galactosidase complex. Biochim Biophys Acta. 1997;1341:189-199.

40. Jackman HJ, Tan F, Tamei H, Beureling-Harbury C, Li XY, Skidet RA, Erdos EG. A deamidase in human platelets that deamidates tachykinins: probable identity with the lysosomal "protective protein". J Biol Chem. 1990;265:11265-11272.

41. Gacko M, Worowska A, Woźniak A, Jedynak M, Panek B, Lapiński R. Lysosomal carboxypeptidase A]. Postepy Biochem. 2005;51:162-70.

42. Lehman A, Mattman A, Sin D, Pare P, Zong Z, d'Azzo A, Campos Y, Sirrs S, Hinek A. Emphysema in an adult with galactosialidosis linked to a defect in primary elastic fiber assembly. Mol Genet Metab. 2012; epub ahead of print doi: 10.1016/j.ymgme.2012.02.004.

43. Bielicki J, Hopwood JJ. Human liver N-acetylgalactosamine 6-sulphatase. Purification and characterization. Biochem J. 1991;279(Pt 2):515-520.

44. Turk D, Janjic V, Stern I, Podobnik M, Lamba D, Dahl SW, Lauritzen C, Pedersen J, Turk V, Turk B. Structure of human dipeptidyl peptidase I (cathepsin C): exclusion domain added to an endopeptidase framework creates the machine for activation of granular serine proteases. EMBO J. 2001;20:6570-6582.

Submitted: 6 August, 2011

Accepted after reviews: 20 December, 2011 